\title{
In situ observations of the crystallization of beryl and phenakite in aqueous solutions in a hydrothermal diamond-anvil cell
}

\author{
JIANKANG $\mathrm{LI}^{1}$, XIAN WANG ${ }^{2}$, AND I-MING $\mathrm{CHOU}^{3}$ \\ ${ }^{1}$ Institute of Mineral Resources, Chinese Academy of \\ Geological Sciences, Beijing 100037, China \\ (1i9968@126.com) \\ ${ }^{2}$ China University of Geoscineces (Beijing), Beijing 100083 \\ (elvirawangxian@163.com) \\ ${ }^{3}$ Institute of Deep-sea Science and Engineering, Chinese \\ Academy of Sciences, No. 28 Luhuitou Rd., Sanya, \\ Hainan Province 572000, China (imchou@idsse.ac.cn)
}

Beryl and phenakite are important industrial beryllium minerals. In the hydrous melt of the $\mathrm{BeO}-\mathrm{Al}_{2} \mathrm{O}_{3}-\mathrm{SiO}_{2}-\mathrm{H}_{2} \mathrm{O}$ (BASH) system, the transition between beryl and phenakite can occur in the reaction of beryl $+\mathrm{H}_{2} \mathrm{O}=$ chrysoberyl + phenakite $+\mathrm{SiO}_{2}$, or beryl $+\mathrm{H}_{2} \mathrm{O}=$ euclase + phenakite + $\mathrm{SiO}_{2}$. Beryl and phenakite are stable at different pressuretemperature $(P-T)$ conditions, based on the experimental results using quench-type high- $T$ and high- $P$ equipment [1].

Here, we observed in situ crystallization process of phenakite and beryl in an aqueous solution of the beryl $\left(\mathrm{Be}_{3} \mathrm{Al}_{2}\left(\mathrm{SiO}_{3}\right)_{6}\right)-\mathrm{H}_{2} \mathrm{O}$ system in a hydrothermal diamond anvil cell (HDAC). In our experiments, phenakite began to crystallize while the originally loaded beryl was dissolving during heating above $\sim 450{ }^{\circ} \mathrm{C}$ (at the corresponding $P$ s of $\sim 200 \mathrm{MPa}$ ), and phenakite continued to grow during cooling from the upper $T$ limits of that particular HDAC (845$870{ }^{\circ} \mathrm{C}$ ), where beryl was totally dissolved at the corresponding $P$ s of 500-1300 MPa. However, in some cases, beryl was not totally dissolved at these $T \mathrm{~s}$ and it began to recrystallize with the dissolution of phenakite during cooling. In the phenakite crystallization experiments during heating and cooling, it crystallized in a columnar shape, and therefore it is easy to calculate its crystallization rates. For example, one phenakite crystal in our experiments was observed to grow at the rates of $0.58-2.90 \times 10^{-5} \mathrm{~cm} / \mathrm{s}$ in length and $3.23-$ $22.39 \mu \mathrm{m}^{3} / \mathrm{s}$ in volume. These rates are higher than those crystallized from a hydrous melt [2], indicating the higher diffusion rates of components in aqueous solution than in melt. In our future studies, more experiments will be performed in HDAC to observe the transition between beryl and phenakite at fixed $P-T$ conditions for extended experimental durations.

[1] Franz \& Morteani (2002) Rev. Mineral. Geochem., 50, 551-589. [2] Sirbescu et al. (2017) J. Petrol., 58, 539-568. 